\title{
Relationships between Phonological, Lexical, and Grammatical Skills in 18- to 30-Month-Old Korean Children
}

\author{
Minkyeong $\mathrm{Pi}^{\mathrm{a}}$, Seunghee $\mathrm{Ha}^{\mathrm{b}}$ \\ ${ }^{a}$ Graduate Program in Speech Language Pathology, Hallym University, Chuncheon, Korea \\ ${ }^{b}$ Division of Speech Pathology and Audiology, Audiology and Speech Pathology Research Institute, Hallym University, Chuncheon, Korea
}

Correspondence: Seunghee $\mathrm{Ha}, \mathrm{PhD}$ Division of Speech Pathology and Audiology, Audiology and Speech Pathology Research Institute, Hallym University, 1 Hallimdaehak-gil, Chuncheon 24252, Korea

Tel: +82-33-248-2215

Fax: +82-33-256-3420

E-mail: shha@hallym.ac.kr

Received: January 5, 2018

Revised: February 9, 2018

Accepted: February 9, 2018
Objectives: This study examined phonological, lexical, and grammatical skills in the spontaneous speech of children between 18- to 30-months of age and the relationship of these skills to speech-language processing. Methods: Twelve children age 18-24 months and twelve children age 25-30 months participated in the study. Fifty utterances from each child were collected during spontaneous speech and analyzed using measures in three categories: phonological (PMLU, PWP, PWC, PCC, FMLU), lexical (NDW, NTW), and grammatical (NDGM, NTGM, TTRgm, MLUw, MLUm). Multivariate analysis of variance was used to examine age group differences, and the correlation between phonological, lexical, and grammatical skills. Results: Analysis of PMLU, FMLU, NDW, NTW, NDGM, NTGM, MLUw, and MLUm revealed that the 25 - to 30-month-old children's results were significantly higher. A significant positive correlation was apparent between several of the phonological and lexical measures in the 18- to 24-month-old group; however, several of the phonological and grammatical measures revealed significant positive and negative correlations. Conclusion: These findings suggest that before 2 years of age, there appear to be tradeoffs between phonological and grammatical skills; however, when a child reaches 2 years of age, language development has progressed so that phonological and grammatical skills are interdependent.

Keywords: 18- to 30-month-old children, Spontaneous speech, Phonological skills, Language skills
생후 12 개월 전후로 나타나는 첫 낱말 산출은 아동이 언어 단계 로 전환하기 시작한 의미 있는 사건이다. 언어 단계가 시작된 이후, 생후 18 개월 경부터는 음운, 어휘, 구문, 형태소 사용 측면에서 비약 적인 발달기를 맞는다. 이 시기 아동의 음운 특성을 살펴본 연구들 에 따르면, 생후 18-36개월은 말소리 목록의 증가뿐 아니라 평균음 운길이(phonological mean length of utterance, PMLU)가 길어지 고, 단어단위 근접률(phonological word proximity, PWP)과 단어 단위 정확도(phonological word correction, $\mathrm{PWC}$ )가 높아지며, 자 음정확도(percentage of consonants correct, PCC)와 말 명료도가 향상된다(Ha \& Hwang, 2013; Ha, Seol, So, \& Pae, 2016; Jung, Pae
\& Kim, 2006). 어휘 발달 측면에서 아동은 $17-19$ 개월 사이에 평균 50개의 어휘를 말하게 된다(Bates, Dale, \& Thal, 1995; Chang-Song, 2004). 2 세 전후로 어휘가 급속도로 증가하는 '어휘 폭발기(Dore, 1979)'가 나타나는데, 이로 인해 2 세에 걸쳐 아동의 자발화에서 서 로 다른 낱말 수와 총 낱말 수도 지속적으로 증가한다(Ha et al., 2016). 표현 어휘가 50 여 개를 넘어서면서 아동은 단어를 조합하여 산출하기 시작한다. 초기에 나타나는 문장은 단순히 단어를 나열 하는 형태이지만 곧 격조사, 접속조사, 보조사, 종결어미와 같은 문 법형태소를 포함한 문장이 나타난다(Kim, 1997).

아동의 초기 언어 습득과정에서 음운, 어휘, 문법 영역이 균형적 
으로 발달하는지, 아니면 특정 영역에 인지적 용량이 집중되었을 때 다른 영역에서의 오류가 높아지는지에 대해서는 의견이분분하다. Bock (1982)은 언어를 생성, 처리 및 산출하는 과정에서 아동의 작 업기억 용량의 한계로 인한 언어 영역 간 상호작용이 있다고주장하 였다. 예를 들어 아동 발화에서 빈번하게 관찰되는 단순화나 오류 는 언어처리과정의 용량상 제한으로 인해 특정 영역에 초점이 맞춰 져 발현된다고 제안하였다. 즉 어린 아동에게서 나타나는 단순화나 오류는 인지 부하로 인한 언어처리과정의 제약으로 설명할 수 있다. 언어 구조가 복잡해질수록음소 목록이 제한적이거나 말산출 정확 성이 떨어지는 반면, 말소리 산출이 다양하거나 정확할수록 문장 구조나 표현 어휘가 단순화된다. 이것은 초기 언어 습득과정에서 관찰되는 언어와 말 사이의 교환관계(tradeoff)라 할 수 있다.

아동에게 나타나는 언어 영역 간 교환관계를 제안하거나 암시한 연구결과들이 있다. Streim과 Chapman (1987)은 어휘 접근성(lexical accessibility), 즉 어휘심성집(lexicon)에 저장된 어휘에 접근하 고 인출하는 능력이 문장 산출에 영향을 주는 요인을 분석함으로 써 아동의 어휘와 구문 능력 간의 관계에 대해서 살펴보았다. 이들 은 아동이 문장 산출과제를 실시할 때 필요한 목표 어휘를 미리 제 공한 경우, 6-8세 아동이 산출한 발화 길이가 더 길어졌다고 보고 하였다. 즉, 표현해야 하는 어휘를 직접 제시하였을 때 구문 능력이 향상되었다는 점을 보여주었다.

국내에도 어휘와 음운의 관계를 살펴보기 위해 진행된 연구가 있다. 한국 2 세 아동의 자발화와 공식검사 결과를 바탕으로 어휘 능력과 음운 능력의 상관관계를 살펴본 연구 결과에 따르면, 자발 화의 서로 다른 낱말 수(number of different word, NDW)는 단어 단위 정확도(PWC), 평균음운길이(PMLU), 단어단위 근접률(PWP), 자음정확도 $(\mathrm{PCC})$ 와 정적 상관을 보였다고 한다(Choi, Kim, \& $\mathrm{Kim}, 2014)$. 이는 한국 2세 아동에게서 어휘와 음운이 함께 발달한 다는 점을 나타낸다.

구문 및 문법형태소와 음운의 관계에 대해 초점을 맞춘 Donahue (1985)에 따르면, 한 낱말기에서 두 낱말 조합기로 전이 중인 아 동은 어휘나 문법형태소가 추가될수록 자신이 산출하기 용이한 형 태로 말소리를 선택하거나 음절을 축약하는 형태의 전략이 나타난 다고 하였다. 이런 교환관계는 두 낱말 조합 시기를 늦출 뿐 아니라, 단어 조합이 시작된 후에도 단어 선택에 영향을 줄 수 있는 요인이 라고 하였다. 즉, 아동은 낱말 조합을 시도하면서 말소리를 대치하 거나 생략하는 산출 오류가 빈번하게 나타나는 말소리 제약이 나 타날 수 있으며, 말산출에서의 제약이 구문 형성에도 영향을 줄 수 있다는 점을 시사하였다. 또한, Nelson과 Kamhi (1984)는 어린 아 동을 대상으로 아동의 구문 복잡성이 음운 측면에 영향을 미칠 수
있다는 사실을 밝혔는데, 흥미롭게도 이런 음운 복잡성과 구문 복 잡성 간의 교환관계는 단단어 구문 단계에서 단어 조합기로 넘어 가는 전이 단계에 주로 발생한다고 하였다.

반면에 음운, 어휘, 또는 문법 측면 간의 교환관계보다는 각 영역 이 서로 영향을 주고 받으면서 균형적으로 발달한다는 결과를 보 여주는 연구도 있다. 어휘와 음운에 대해 살펴본 Storkel과 Morrisette (2002)는 아동이 새로운 단어를 학습할 때 어휘 표상과 음운 표상이 유기적으로 작용하여 어휘 발달과 음운 발달이 서로 영향 을 준다는 양방향적 관계를 주장하였다. 또한 Kamhi, Catts와 Davis (1984)는 22-34개월 아동을 살펴보았을 때 높은 수준의 구문을 산출하는 아동의 음운 정확성이 더 높았으며, 길거나 복잡한 구문 을 사용한다고 음운 정확성이 떨어지지 않는다는 점을 밝혔다. 이 는 구문 복잡성과 음운 정확성 간에 교환관계가 나타나지 않는다 는 점을 시사한다.

18-30개월 아동들은 음운과 언어 능력이 빠르게 성장하여 새로 운 말소리 습득, 말소리 구조의 다양화, 급격한 어휘 성장, 단어 조 합 시도 및 여러 문법형태소 사용이 이루어지기 시작하는 시기이 다(Choi et al., 2014; Ha et al., 2016; Hong \& Sim, 2002; Jung et al., 2006; Pi \& Ha, 2017). 국내에 2세 전후 아동을 대상으로 말-언어 측 면의 발달을 살펴본 연구들은 있으나 객관적 측정치로 발달을 살 펴보는 것에 그쳤다. 이 시기의 아동들은 말과 언어가 균형 잡힌 상 태로 점진적으로 성장하기도 하지만, 다양한 어휘 혹은 긴 구문을 산출하는 대신 말소리 정확도가 떨어지거나 혹은 그 반대의 모습 이 관찰되기도 한다. Choi 등(2014)의 연구에서 2세 아동의 어휘와 음운 능력의 상관관계를 살펴보았을 때, 어휘와 음운 사이에는 교 환관계가 나타나지 않았다. 우리말 음운 발달은 영어권에 비해 쉽 고 빠르게 진행되기 때문에, 인지적 제약으로 인한 일시적 교환 관 계가 2 세 이전에 관찰될 가능성이 있다. 또한 18 개월 이후부터 아 동 발화에서 점차 문법형태소가 출현하고 구문 길이가 증가하므로 문법 측면과 음운 측면의 관계를 살펴보는 것 또한 중요하다. 아동 들이 특정 영역에 초점을 맞춰 발달하는 시기가 있는지, 언어의 특 정 영역 간에 교환 관계가 관찰되는지, 아니면 모든 시기에 음운, 어 휘, 문법 영역에서 균형 잡힌 발달이 일어나는지 알아본다면 말늦 은 아동이나 언어발달지연을 보이는 아동들에게 중재를 제공할 때 어떤 영역에 초점을 맞출지 판단하는 데 이정표가 될 것이다. 본 연 구의 목적은 $18-30$ 개월 한국 아동의 자발화에 나타난 음운 능력과 어휘 및 문법 능력을 살펴본 뒤 상관관계를 살펴보고, 이 시기 아동 에게서 나타나는 말-언어 처리과정 내 특정한 관계가 존재하는지 밝히는 것이다. 


\section{연구방법}

\section{대상자}

본 연구는 18-30개월 사이에 있는 일반 아동 24 명(남 10 명, 여 14 명)을 대상으로 하였다. 대상 아동은 양육자로부터 (1) 출생 및 발 달상 문제가 나타나지 않았다고 보고되고, (2) 영아선별 교육진단 검사(DEP; Jang, Seo, \& Ha, 2009)에서 모든 영역이 백분위 35\%ile 이상으로 정상 발달에 속하며, (3) 한국판 맥아더-베이츠 의사소통 발달평가(K M-B CDI; Pae \& Kwak, 2011)에서 표현어휘 수가 연령 집단별 평균에서 $10 \%$ ile 이상, (4) 영유아 언어발달검사(SELSI; Kim, Kim, Yoon, \& Kim, 2003)에서 수용 및 표현언어가 10\%ile 이상인 아동이 포함되었다. 월령에 따라 아동의 언어 및 음운 능력을 세밀 하게 살펴보기 위해, 생후 $18-24$ 개월 아동 집단(남 4 명, 여 8명)과 25-30개월 아동 집단(남 6명, 여 6명)으로 구분하였다. 연구 대상자 의 기본 정보는 Table 1 에 제시하였다.

\section{자료수집}

연구 절차는 한림대학교 생명윤리위원회의 승인(No. HIRB-2015065)을 받아 진행되었다. 자발화 수집은 언어병리학전공 대학원생 이 대상자의 가정에 방문하여 이루어졌다. 자발화 수집은 총 40 분 간 수집되었는데, 양육자와 검사자가 각 20 여 분 동안 아동들이 쉽 게 접할 수 있는 장난감(주방놀이, 목욕놀이, 낚시놀이, 자동차, 공, 딸랑이, 책)을 이용해 아동과 상호작용하였다. 모든 상호작용 상황 은 캠코더(Samsung HMX-H205BD)와 음성 녹음기(SONY ICDPX333)를 통해 녹화 및 녹음되었다.

\section{자료분석}

상호작용 자료는 수집 후 2 주 이내에 영상 및 녹음 자료를 토대로 전사를 진행하였다. 전사는 아동의 목표 형태 및 음성 전사를 함께 기록하였다. 아동의 활발한 상호작용을 관찰하기 위해 상호작용 자료의 전반부 3 분과 후반부 2 분은 제외하였으며, 부모상호작용 15 분, 검사자 상호작용 15 분 자료가 전사되었다. 전사가 완료된 후 에는 녹음 자료를 다시 듣고 음성 전사가 정확하게 이루어졌는지 재확인하였다. 전사 원칙은 Jung 등(2006)을 참조하여 자료를 3 번

Table 1. Participants' information

\begin{tabular}{lccc}
\hline & \multicolumn{2}{c}{ Age group } & \multirow{2}{*}{ Total ( $\mathrm{N}=24)$} \\
\cline { 2 - 3 } & $18-24 \mathrm{mo}(\mathrm{N}=12)$ & $25-30 \mathrm{mo}(\mathrm{N}=12)$ & \\
\hline Gender (boy:girl) & $4: 8$ & $6: 6$ & $10: 14$ \\
Age (mo) & $21.33(2.02)$ & $27.33(1.61)$ & $24.33(3.55)$ \\
\hline
\end{tabular}

반복해서 들어도 전사가 불가능한 발성이나 발화는 전사하지 않았 으며, 모방과 자발화를 구분하지 않고 모두 전사하였다. 전사된 자 료 중 감탄사나 간투사만으로 이루어진 발화 및 음절성 발성이나 자곤처럼 의미가 분명하지 않은 발화는 분석에서 제외하였으며, 대 답하기 기능으로 산출한 '네, 응/어’는 첫 번째로 산출된 것만 발화 로 포함시켰다. 모든 분석치는 아동이 산출한 발화 중 연속 50 개 발 화를 선정하여 분석하였다. 연속 50 개 발화는 전체 전사 자료에서 아동별 전체 발화 수의 중앙값을 구하여, 중앙값 전후의 발화를 25 개씩 택하는 방식으로 선정하였다.

어휘 지표와 문법 지표의 분석은 한국어 발화분석(Korean Language Analysis, http://kla.hallym.ac.kr/) 프로그램을 사용하였다. KLA 프로그램은 발화 전사를 기반으로 낱말 경계는 띄어 쓰고, 문 법형태소 경계는 '”로 구분하여 코딩하였을 때 언어 지표가 자동적 으로 분석되는 프로그램이다. 가령 아동의 발화의 목표 형태가 “곰 돌이한테 가자”였고 ‘곰돌이’를 반복하였다면 “(곰돌이) 곰돌이/한 테 가/자"로 코딩하였다. 코딩 시 발화 내에 나타난 단어 반복, 구 반 복, 문장 반복은 모두 괄호 안에 넣어 낱말과 문법형태소 분석에서 제외하였다.

\section{음운 지표}

어린 아동의 음운 능력을 살펴보는 분석치 중에는 평균음운길 이(PMLU), 단어단위 근접률(PWP), 단어단위 정확률(PWC)과 같 은 단어단위 음운 지표와 자음정확도(PCC)가 있다. PCC는 (정조 음한 자음 수)/(전체 산출된 자음 수) $\times 100$ 으로 산출하며 임상현 장과 다수 연구들에서 아동의 음운 능력을 살펴보기 위해 쓰이고 있다(Shriberg \& Kwiatkowski, 1982).

하지만 PCC는 음소 단위로 음운 능력을 평가하는 측정치이므 로 낱말 전체로 음운을 습득하는 2 세 전후 어린 아동들에게는 이 측정치가 음운 능력을 완전히 대변하기에 적절하지 않을 수 있다. 따라서, 여러 문헌에서는 단어단위로 음운 능력을 측정하는 방법 을 제안하고 있다(Ingram, 2002; Park, Hwang, \& Park, 2011; Shin \& Lee, 2015; Yoon, Kim, \& Kim, 2013). 단어단위 음운 지표의 분석 기준은 Yoon 등(2013)을 참조하여 사용하였다. PMLU는 아동이 자음을 생략하지 않고 산출하였는지, 자음을 정확하게 산출하였 는지에 따라 점수를 부여하므로 PCC에 비해 자음 산출 면에서 보 다세밀하게 살펴보는 측정치이다. $\mathrm{PMLU}$ 의 계산은 아동이 산출한 자음과 모음에 1점을 부여한 뒤 정조음한 자음과 이중모음에 1점 을 추가하였다. 성인 발화를 기준으로 한 목표 형태와 비교하였을 때 아동이 추가한 음소나 음절은 점수를 주지 않았다. 아동 발화의 전체 점수를 합산한 뒤 발화 수로 나누어서 발화당 평균음운길이 
를 도출하였다. PWP는 아동 발화가 성인 발화와 비교하였을 때 얼 마나 정확하게 근접하였는가를 알 수 있으며, (아동 발화의 PMLU)/ (목표 형태 발화의 PMLU)로 계산하였다. 단어단위 정확률(PWC) 은 (아동이 정확하게 산출한 어절 수)/(전체 어절 수)로 산출하였다. PWC도 PWP처럼 목표 형태와 아동 발화를 비교하지만, PWC는 단어나 어절 전체를 기준으로 정확도를 판단하기 때문에 PWP보 다는 개략적으로 성인 발화와 형태를 비교한다고 볼 수 있다. 어절 은 표준어 띄어쓰기를 원칙으로 구분하되, 본용언과 보조용언, 부 정어와 동사, 관형어와 불완전명사, 수사와 단위가 결합된 경우 두 개의 어절을 하나로 보았다(Yoon et al., 2013).

본 연구에서 추가적으로 살펴보는 음운 능력 측정치는 평균자질 길이(feature mean length of utterance, FMLU)이다(Ha \& Kim, in press). FMLU는 아동의 단어 수준 내지는 음소 수준 오반응을 '오 류로 판단하여 점수를 부여하지 않았던 기존 측정치와 달리, 아동 이 정조음을 하지 못하는 음소도 변별 자질에 따라 가중치를 부여 하는 측정치이다. FMLU는 기본적으로 PMLU처럼 아동이 산출한 자음과 모음에 각각 1 점을 준다. 그 다음 조음 난이도에 따라 초성, 중성, 종성에 부가 점수를 부여한다. 자세히 살펴보면 초성은 조음 위치, 조음 방법, 발성 유형이 어떤가에 따라 부가 점수가 달라진다. 먼저 초성의 경우, 조음 위치가 정확하면 1점을 주었다. 만약 초성 자음이 파열음인 경우, 발성 유형이 동일할 때 1 점을 추가하고, 파 찰음이나 치조 마찰음, 비음, 유음이라면 조음 방법이 정확할 때 1 점을 추가하였다. 앞서 언급된 자음이 아닌 성문 마찰음 /ㅎ/은 부 가 점수가 없다. 둘째로 중성의 경우, 단모음을 정확하게 산출하였 을 경우 1 점을 주었다. 이중모음을 정확하게 산출하였을 경우 1 점 을 추가하였다. 마지막으로 종성의 경우, 어말 종성을 정확하게 산 출한 경우 1 점을 추가하고, 어중 종성은 비음일 경우에만 1 점을 추 가하였다. 그 다음 계산한 전체 점수를 모두 합하여 발화수로 나누 었다. 이처럼 FMLU는 초성, 중성, 종성 모두를 대상으로 음소의 자 질을 고려하여 세밀하게 아동의 음운 능력을 살펴보는 점수 체계이 다. 2 세 전후 아동의 주된 음운 변동은 대치와 생략이므로 FMLU 는 이 시기 아동들의 음운 능력을 살펴보기에 적합할 것이다.

\section{어휘 지표}

아동의 자발화를 기반으로 어휘 능력을 살펴본 연구에서는 서로 다른 낱말 수(NDW)와 총 낱말 수(number of total word, NTW) 를 주로 이용하였다(Choi et al., 2014; Ha et al., 2016). 이 측정치들 은 아동의 어휘 수와 어휘 산출 빈도에 대해 알 수 있다. 따라서 본 연구에서 어휘 지표는 NDW, NTW를 포함하였다.

\section{문법 지표}

본 연구에서는 아동이 자발화에서 문법형태소를 다양하게 산출 하는지 측정하기 위해 문법형태소 유형 수(number of different grammatical morphemes, NDGM), 총 문법형태소 수(number of total grammatical morphemes, NTGM), 문법형태소 다양도(type-token ratio of grammatical morphemes, TTRgm)를 살펴보고자 한 다. 문법형태소 유형 수(NDGM)는 자발화에 나타난 서로 다른 문 법형태소의 개수를 이르며, 총 문법형태소 수는 자발화에 나타난 전체 문법형태소를 말한다. 문법형태소 다양도는 문법형태소 유형 수를 총 문법형태소수로 나눈 것으로 아동이 전체 문법형태소사용 량 대비, 얼마나 다양한 문법형태소를 사용하는지 살펴볼 수 있다.

평균발화길이(mean length of utterance, MLU)는 아동 발화에 포함된 낱말 수(mean length of utterance in words, MLUw)나 형태 소 수(mean length of utterance in morphemes, MLUm)의 평균을 구하는 측정치이다. MLUw와 MLUm은 자발화 표본을 분석하는 연구에서 구문 길이를 정량화하기 위해 사용되었으므로(Ha et al., 2016; Lee, \& Kim, 1999), 아동의 구문 복잡성을 측정하기에 도움이 될 것이다.

\section{신뢰도}

자료의 전사 신뢰도와 측정치의 분석 신뢰도를 위해 전체 자료 의 약 $17 \%$ 를 임의로 선정하여 전사자 간 신뢰도 및 분석자 간 신뢰 도를 구하였다. 전사자 간 신뢰도와 분석자 간 신뢰도는 제 1 저자와 언어병리학전공 대학원생이 독립적으로 분석한 자료를 비교하였 다. 전사 신뢰도는 (일치한 자음 수)/(전체 자음 수 $) \times 100$ 으로 계산 한 결과, $91.45 \%$ 였다. 언어 지표는 전사 자료의 문법형태소 경계를 나누는 코딩작업이 선행된 후, KLA 프로그램을 통해 자동으로 분 석된다. 따라서, 언어 지표의 신뢰도는 문법형태소 경계의 코딩이 일관적으로 수행되었는지가 중요하다. 문법형태소 경계에 대한 코 딩 일치도는 $($ 일치한 코딩 위치)/(제 1 저자의 코딩 위치 $) \times 100$ 으로 산출하였다. 그 결과, 분석자 간 신뢰도는 $93.07 \%$ 로 나타났다. 음운 지표는 Cohen's Kappa를 이용하여 분석자 간 신뢰도를 측정하였 다. 음운 지표 분석 결과, PMLU .911, PWP .926, PWC .947, PCC $.952, \mathrm{FMLU} .903$ 으로 높은 분석자 간 신뢰도가 나타났다.

\section{통계 분석}

통계 처리는 SPSS version 22.0 프로그램을 사용하였다. 자발화 에서 수집된 측정치의 지표별 상관관계를 살펴보았을 때, 대다수 높은 상관관계가 나타났다. 따라서 월령 집단 간 차이를 살펴보기 위해 다변량 분산분석(multivariate analysis of variance, MANO- 
$\mathrm{VA})$ 을 실시하였다. 부분 에타제곱 $\left(\eta_{\mathrm{p}}^{2}\right)$ 값을 통해 집단 간 차이에 대 한 효과 크기를 살펴보았다. 언어 지표와 음운 지표 간의 상관관계 는 Pearson 상관계수를 통해 살펴보았다. 모든 유의수준은 $p<.05$ 로 설정하였다.

\section{연구결과}

월령 집단별로 측정치 간 차이를 비교하기 이전에, 성비가 결과 에 영향을 미치는지 먼저 살펴보았다. 월령 집단별로 성별에 따른 음운, 어휘, 문법 능력에 차이가 있는지 검증하기 위해 모든 측정치 에 대해 독립표본 $t$-검정을 실시하였다. 그 결과, 전체 아동 집단, 18-24 개월 아동 집단과 25-30개월 아동 집단에게서 어휘 지표(NDW, NTW, TTRw), 문법 지표(NDGM, NTGM, TTRgm, MLUw, MLUm), 음운 지표(PMLU, PWP, PWC, PCC, FMLU)에서 성별에 따른 유 의미한 차이는 나타나지 않았다( $p>.05)$.

\section{음운, 어휘 및 문법 능력의 발달}

음운, 어휘, 문법 지표별 하위 측정치에 따라 월령 집단 간 차이를 살펴본 결과를 Table 2에 제시하였다. 연속 50개 발화에서 PMLU 는 6.72에서 8.70으로 유의하게 증가하였으며, FMLU도 9.97에서 15.22로 유의하게 증가하였다. PWP, PWC, PCC는 월령이 증가하 였을 때 유의한 차이가 나타나지 않았다.

$18-24$ 개월 아동의 연속 50 개 발화에 나타난 NDW는 약 31 개였 으나, 25-30개월 아동은 약 43개를 산출하여 유의하게 증가하였다. NTW도 월령이 증가함에 따라 약 66 개에서 약 91 개로 유의하게 증 가하였다.

구문 지표에서도 TTRgm을 제외한 모든 측정치가 25-30개월 아 동 집단에서 유의하게 높게 나타났다. 음운 지표에서는 25-30개월 아동 집단에서 유의미하게 높은 측정치가 PMLU와 FMLU로 나타 났다.

월령 집단에 따라 음운 지표의 합산 점수, 어휘 지표의 합산 점

Table 2. Age group comparisons for all subtype measures

\begin{tabular}{|c|c|c|c|c|c|}
\hline & $18-24$ mo & 25-30 mo & $F$ & $p$-value & $\eta_{p}^{2}$ \\
\hline \multicolumn{6}{|c|}{ Phonological measure } \\
\hline PMLU & $6.72(1.29)$ & $8.70(2.01)$ & 8.212 & .009 & .272 \\
\hline PWP & $.80(.10)$ & $.81(.06)$ & .169 & .685 & .008 \\
\hline PWC & $.47(.17)$ & $.47(.07)$ & .001 & .976 & $<.001$ \\
\hline PCC & $64.20(14.20)$ & $65.77(5.97)$ & .124 & .728 & .006 \\
\hline FMLU & $9.97(2.21)$ & $15.22(3.82)$ & 16.982 & $<.001$ & .436 \\
\hline \multicolumn{6}{|c|}{ Lexical measure } \\
\hline NDW & $31.58(10.37)$ & $43.75(11.39)$ & 111.310 & $<.001$ & .910 \\
\hline NTW & $66.67(16.21)$ & $91.08(21.52)$ & 203.093 & $<.001$ & .949 \\
\hline \multicolumn{6}{|c|}{ Grammatical measure } \\
\hline NDGM & $9.83(4.80)$ & $18.42(7.57)$ & 10.994 & .003 & .333 \\
\hline NTGM & $22.83(12.64)$ & $49.08(22.65)$ & 12.294 & .002 & .358 \\
\hline TTRgm & $50.77(20.99)$ & $38.86(10.36)$ & 3.107 & .092 & .124 \\
\hline MLUw & $1.37(.24)$ & $1.81(.43)$ & 9.427 & .006 & .300 \\
\hline MLUm & $1.83(.46)$ & $2.79(.83)$ & 12.253 & .002 & .358 \\
\hline
\end{tabular}

Values are presented as mean (SD).

NDW = number of different words; NTW = number of total words; NDGM= number of different grammatical morphemes; NTGM= number of total grammatical morphemes; TTRgm = type-token ratio of grammatical morphemes; MLUw=mean length of utterance in morphemes; MLUm=mean length of utterance in words; PMLU=phonological mean length of utterance; PWP = phonological word proximity; $P W C=$ phonological word correction; $P C C=$ percentage of consonants correct; $F M L U=$ feature mean length of utterance.

Table 3. Age group comparisons for phonological and language measures

\begin{tabular}{lcccrrr}
\hline & $18-24 \mathrm{mo}$ & $25-30 \mathrm{mo}$ & Wilks' $\lambda$ & $F$ & $p$-value & $\eta_{\mathrm{p}}{ }^{2}$ \\
\hline Phonological measure & $82.00(15.65)$ & $93.41(10.63)$ & .541 & 3.055 & .036 & .459 \\
Lexical measure & $98.25(24.00)$ & $134.83(31.96)$ & .050 & 94.709 & $<.001$ & .950 \\
Grammatical measure & $86.65(16.70)$ & $110.97(30.35)$ & .591 & 2.492 & .070 & .409 \\
\hline
\end{tabular}

Values are presented as mean (SD). 
Table 4. Correlations between phonological and language measures at 18-24 months of age

\begin{tabular}{cllllll}
\hline & & \multicolumn{5}{c}{ Phonological measure } \\
\cline { 3 - 7 } & & PMLU & PWP & PWC & PCC & FMLU \\
\hline Lexical & NDW & .520 & .302 & -.007 & .133 & .353 \\
measure & NTW & $.875^{* *}$ & $.670^{*}$ & .395 & .502 & $.836^{* *}$ \\
Grammatical & NDGM & $.678^{*}$ & .454 & .199 & .308 & $.628^{*}$ \\
measure & NTGM & $.693^{*}$ & .464 & .374 & .349 & $.685^{*}$ \\
& TTRgm & -.380 & $-.643^{*}$ & $-.578^{*}$ & -.559 & -.336 \\
& MLUw & $.938^{* *}$ & .442 & .222 & .300 & $.960^{* *}$ \\
& MLUm & $.863^{* *}$ & .474 & .314 & .340 & $.872^{* *}$ \\
\hline
\end{tabular}

NDW = number of different words; NTW = number of total words; NDGM = number of different grammatical morphemes; NTGM=number of total grammatical morphemes; TTRgm = type-token ratio of grammatical morphemes; MLUW= mean length of utterance in morphemes; MLUm= mean length of utterance in words; PMLU= phonological mean length of utterance; $\mathrm{PWP}=$ phonological word proximity; $\mathrm{PWC}=$ phonological word correction; $\mathrm{PCC}=$ percentage of consonants correct; $\mathrm{FMLU}=$ feature mean length of utterance.

${ }^{*} p<.05,{ }^{* *} p<.01$.

Table 5. Correlations between phonological and language measures at 25-30 months of age

\begin{tabular}{ccccccc}
\hline & & \multicolumn{5}{c}{ Phonological measure } \\
\cline { 3 - 7 } & & PMLU & PWP & PWC & PCC & FMLU \\
\hline Lexical & NDW & .153 & .012 & -.414 & -.097 & $.732^{* *}$ \\
measure & NTW & .285 & .091 & -.479 & -.032 & $.897^{* *}$ \\
Grammatical & NDGM & .391 & .304 & .145 & .243 & $.868^{* *}$ \\
measure & NTGM & .266 & -.118 & .159 & -.106 & $.939^{* *}$ \\
& TRgm & .350 & $.754^{* *}$ & .044 & $.639^{*}$ & -.227 \\
& MLUw & .278 & .066 & -.466 & -.048 & $.900^{* *}$ \\
& MLUm & .290 & -.036 & -.155 & -.086 & $.985^{* *}$ \\
\hline
\end{tabular}

NDW = number of different words; NTW = number of total words; NDGM = number of different grammatical morphemes; NTGM= number of total grammatical morphemes; TRgm = type-token ratio of grammatical morphemes; MLUw= mean length of utterance in morphemes; $M L U m=$ mean length of utterance in words; PMLU= phonological mean length of utterance; $\mathrm{PWP}=$ phonological word proximity; $\mathrm{PWC}=$ phonological word correction; $\mathrm{PCC}=$ percentage of consonants correct; $F M L U=$ feature mean length of utterance.

${ }^{*} p<.05,{ }^{* *} p<.01$.

수, 구문 지표의 합산 점수를 비교하여 Table 3에 제시하였다. 음운 지표는 18-24개월 아동 집단에 비해 25-30개월 아동 집단의 측정값 이 유의하게 높은 것으로 나타났다(Wilks' $\lambda=.541, F_{(5,18)}=3.055$, $\left.p=.036, \eta_{\mathrm{p}}^{2}=.459\right)$. 어휘 지표는 25-30개월 아동의 측정값이 유의 하게 높은 것으로 나타났다(Wilks' $\lambda=.050, F_{(2,10)}=94.709, p<.001$, $\left.\eta_{\mathrm{p}}{ }^{2}=.950\right)$. 구문 지표도 25-30개월 아동의 측정값이 높았으나 월령 집단 간 유의한 차이는 나타나지 않았고, 중간 수준의 실제적 유의 성을 가진 것으로 나타났다(Wilks' $\lambda=.591, F_{(5,18)}=2.492, p=.070$, $\left.\eta_{\mathrm{p}}{ }^{2}=.409\right)$.
Table 6. Correlation measures by age group

\begin{tabular}{lll}
\hline & \multicolumn{1}{c}{$18-24$ mo } & 25-30 mo \\
\hline Positive correlation & PMLU-NTW & PWP-TTRgm \\
& PWP-NTW & PCC-TTRgm \\
& FMLU-NTW & FMLU-NDGM \\
& PMLU-NDGM & FMLU-NTGM \\
& FMLU-NDGM & FMLU-MLUw \\
& FMLU-MLUw & FMLU-MLUm \\
& FMLU-MLUm & \\
Negative correlation & PWP-TRgm & - \\
& PWC-TRgm & \\
\hline
\end{tabular}

PMLU = phonological mean length of utterance; NTW = number of total words; $P W P=$ phonological word proximity; TTRgm = type-token ratio of grammatical morphemes; $\mathrm{PWC}=$ phonological word correction; $\mathrm{PCC}=$ percentage of consonants correct; FMLU = feature mean length of utterance; NDGM = number of different grammatical morphemes; NTGM= number of total grammatical morphemes; MLUW=mean length of utterance in morphemes; MLUm = mean length of utterance in words.

\section{언어 지표와 음운 지표의 상관관계}

\section{$18-24$ 개월 아동 집단의 언어 지표와 음운 지표의 상관관계}

18-24개월 아동 집단의 어휘 및 문법 측정치와음운 측정치 간의 관계를 살펴보기 위해 상관 분석을 실시한 결과를 Table 4에 제시 하였다. PMLU는 NTW, NDGM과 유의한 정적 상관이 나타났다. $\mathrm{PWP}$ 는 NTW와 정적 상관이 나타난 반면 TTRgm과는 부적 상관 이 나타났다. PWC는 TTRgm하고 부적 상관이 나타났다. PCC는 어떠한 측정치와도 유의한 상관관계가 나타나지 않았으며, FMLU 는 NTW, NDGM, NTGM, MLUw, MLUm과 정적 상관이 나타났다.

\section{5-30개월 아동 집단의 언어 지표와 음운 지표의 상관관계}

25-30개월 아동 집단의 어휘 및 구문 측정치와 음운 측정치 간의 관계를 살펴보기 위해 상관 분석을 실시한 결과를 Table 5에 제시 하였다. PWP와 PCC가 TTRgm과 유의한 정적 상관이 나타났다. FMLU는 NDW, NTW, NDGM, NTGM, MLUw, MLUm과 유의 한 정적 상관이 나타났다.

18-24개월에 유의한 부적 상관이 나타났던 PWP와 TTRgm은 유의한 정적 상관으로 변화하였으며, 또한 유의한 부적 상관을 보 인 PWC와 TTRgm은 통계적으로 유의하지는 않으나 정적 상관 형 태로 변화하였다. 월령 집단별로 통계적으로 유의한 상관이 나타 난 측정치들을 Table 6에 정리하였다.

\section{논의 및 결론}

본 연구는 18-30개월 아동을 24개월 기점으로 두 월령 집단으로 나누어 자발화 50 개를 토대로 어휘 지표, 문법 지표 및 음운 지표의 
산출 양상을 비교하였으며, 음운 지표와 어휘 및 문법 지표 간의 관 계를 살펴보았다.

음운 지표의 발달 양상을 살펴보면, 월령이 증가함에 따라 PMLU 와 FMLU는 유의하게 증가하였으나, PWP, PWC, PCC는 유의하게 증가하지 않았다. 이는 지표 특성의 차이로 볼 수 있다. 아동의 발화 가 성인 발화와 얼마나 근접한 지 살펴보는 PWP, 어절 기준으로 얼 마나 정확한지 살펴보는 PWC는 초기 음운 발달 시기에 있는 18-30 개월 아동들에게 명확한 차이가 나타날 만한 측정치가 아니었다고 볼 수 있다. 마찬가지로 PCC도 자음만을 기준으로 정확도를 보기 때문에 자음의 대치와 생략이 빈번한 18-30개월 아동에게서 6개월 만에 유의하게 발달하는 지표로 볼 수 없다. 하지만, $\mathrm{Ha}$ 등(2016)의 결과에 따르면 24-30개월, 31-36개월 아동 집단 간에는 PWP, PWC, $\mathrm{PCC}$ 에서 유의한 차이가 있었다고 한다. 이러한 연구 결과는 PWP, $\mathrm{PWC}, \mathrm{PCC}$ 가 1 세 후반과 2 세 전반 사이에 진행되는 음운 발달을 민감하게 반영하지 못할 수 있음을 제안한다.

PMLU는 목표 음소를 산출하였을 때 점수를 부여하고, 정확하 게 산출한 자음 및 이중모음에 추가적인 점수를 주는 측정치이다. 2 세 이전 아동과 2 세 아동 간 PMLU에서 유의한 차이가 난 사실은 아동이 2 세에 이르면서 모음을 정확하게 산출하면서 음절 구조를 지켜 말을 산출한다는 점을 암시한다. FMLU는 아동의 대치 오류 형태를 단순하게 오반응으로 본 것이 아니라 조음 위치, 조음 방법, 발성 유형이 정확했는가에 따라 가산점을 부여하였다. 이 점수 체 계는 아동이 얼마나 자음의 자질을 정확하게 산출하는지 자세히 살펴볼 수 있는 기회를 제공한다. 즉, $18-30$ 개월 아동이 월령이 증가 함에 따라 FMLU가 유의하게 증가하였다는 점은 1 세 후반에 음소 를 생략하는 오류를 보이다가 2 세에는 생략보다 자음의 일부 자질 면에서 오류를 보이는 대치 오류로 변화한 말소리 발달 특성을 반 영한다 할 수 있다. 유의수준과 효과크기를 참조하여 보았을 때, PMLU와 FMLU 중 18-30개월 아동의 음운발달을 더 민감하게 확 인할 수 있는 지표는 FMLU이다. 따라서, 1 세 후반에서 2 세 전반에 이르는 어린 아동이나 말 측면에서 지연을 보이는 아동들에게 본 연구에서 고안된 측정치인 FMLU를 객관적인 지표로 사용하면 발 달 현황을 좀 더 세밀하게 살펴볼수 있을 것이다.

어휘 지표인 NDW와 NTW는 18-30개월 아동에게서 월령이 증 가함에 따라 비약적으로 발전하였다. 이는 생후 18 개월경 어휘 폭 발기를 맞아 아동의 어휘 습득과 사용이 모두 활발하게 이루어진 다는 선행연구 결과와 일치한다(Chang-Song, 2004; Dore, 1979).

구문 지표에서 문법형태소에 대한 측정치인 NDGM, NTGM은 월령이 증가함에 따라 유의하게 증가하였다. 즉, 1 세 후반 아동이 2 세 전반부에 이르면서 약 2 배 정도 다양한 문법형태소를 사용할 수
있게 되며, 문법형태소를 포함한 발화를 2 배 이상 많이 산출하게 되었다는 점을 알 수 있다. 앞선 NDGM과 NTGM의 증가율 차이 로 인해 TTRgm은 감소한 결과가 나타났다. 즉, TTRgm의 감소는 아동의 문법형태소 발달 양상이 자신에게 익숙한 일부 문법형태소 를 반복적으로 산출하는 형태로 나타났기 때문이라고 해석할 수 있다. 실제로 아동 발화를 살펴보면, 1 세 후반에 비해 다양한 문법 형태소를 쓸 수 있게 된 2 세 전반 아동들이 주격조사, 선어말어미, 어말어미 중 일부를 집중적으로 사용하는 모습이 관찰되었다(예: "아빠 갔어?”, "내가 했어.”, “토끼가 먹었어.", “엄마가 해.”; 이 발화 들에서는 시제를 나타내는 선어말어미 '-었-', 어말어미 '-어', 주격 조사'-가'가 반복적으로 사용되었음).

구문 지표에서 구문 길이에 대한 정보를 알아보는 MLUw, MLUm 은 월령이 증가함에 따라 유의하게 증가하였다. 이 두 측정치를 모 두 고려하였을 때, 18-24개월 아동은 한 낱말 표현을 주로 사용하 나 낱말 조합을 시도하는 전이기로 볼 수 있으며, 25-30개월 아동은 두 낱말 조합을 이전보다 더 많이 산출하며 실질형태소가 아닌 문 법형태소가 구문에 한 개 정도 포함된다는 사실을 알 수 있다.

월령 집단 간 음운과 어휘 및 구문 능력의 상관관계를 살펴본 결 과, $18-24$ 개월에는 음운과 어휘, 음운과 구문 측면에서 유의한 정 적 상관이 주로 관찰되었다. 하지만 PWP, PWC와 TTRgm에서 부 적 상관이 나타났다. 이는 아동이 문법형태소를 다양하게 사용할 수록 말소리를 성인 형태로 근접하게 말하거나 정확하게 산출하는 능력이 감소한다는 것이다. 다시 말하면 문법형태소와 음운 능력에 서 교환관계가 일어나고 있다는 사실을 보여준다. 이는 한 낱말 단 계에서 두 낱말 조합기의 전이 단계에 있는 아동에게서 구문 복잡 성과 음운 복잡성 간의 교환관계가 성립한다는 선행연구 결과와 일치한다(Donahue, 1985; Nelson \& Kamhi, 1984). 즉, 18-24개월 아동의 음운, 어휘, 구문 간의 관계는 기본적으로 유기적으로 영향 을 주고받으며 상호의존적인 관계라고 볼 수 있지만, 문법형태소와 음운 면에서는 제한된 인지 능력과 이로 인한 언어처리과정의 부하 로 인해 교환관계가 나타났다고 볼 수 있다.

25-30개월 아동의 통계적으로 유의한 상관관계는 음운과 구문 영역에서 모두 정적 상관이 관찰되었다. 1 세 후반에는 문법형태소 를 다양하게 많이 사용할수록 음운 능력이 손해를 보거나, 말소리 가 정확해지면 문법형태소를 단조롭고 적게 사용하는 패턴을 보였 다. 하지만 2 세에 이르러서는 인지처리용량이 성장하였을 뿐 아니 라 음운과 구문에 대한 경험이 누적되고 말-언어 산출이 자동화되 어 음운과 구문 영역이 균형적으로 발달하고 있음을 제안한다. 또 한 25-30개월 아동의 음운과 어휘 영역에서 정적 상관이 관찰되었 는데 이 결과는 한국 2 세 아동에게서 어휘와 음운이 상호의존적으 
로 발달한다는 연구결과와 일치한다(Choi et al., 2014).

본 연구는 18-30개월 아동을 대상으로 자발화에 나타난 음운, 어휘, 구문의 관계를 살펴보았다. 이 시기의 아동들은 주의 집중과 과제 이해상의 어려움으로 인해 구조화된 실험 조건을 통해 음운, 어휘, 구문 간의 관계를 살펴보는 것이 제한적이므로 자발화를 통 해 각 언어 영역 간의 관계를 살펴보았다. 본 연구 결과는 2 세 이전 아동이 문장을 산출할 때 음운과 구문 중 한 영역에 집중하여 산 출 정확성의 불균형을 초래할 수 있지만, 2 세 이후에는 음운, 어휘, 구문 모두 균형적으로 발달한다는 점을 보여주었다. 이 사실은 말 늦은 아동이나 언어발달지연을 보이는 아동들에게 불균형이 일어 난 언어 영역이 무엇인지 파악하고 정확하게 중재를 제공해야 한다 는 점에 시사하는 바가 있다. 영역 간 발달이 불균형적으로 표출될 만큼 말-언어 발달이 명백하게 지연되었다면 음운, 어휘, 구문 영역 모두에 초점을 맞추는 중재를 제공하는 것이 아니라 미숙한 영역 을 보강하는 방향으로 중재의 초점을 맞추어야 한다. 예를 들어 말 측면에서 지연을 보이는 아동에게는 아동이 자신감 있게 산출할 수 있는 어휘와 구문 구조를 활용하여 말 중재를 실시하는 것이 바 람직할 것이다. 또한 언어가 지연된 아동에게는 아동의 말소리 목 록에 포함된 음소를 활용하여 새로운 어휘를 배우고 구문 구조를 습득하게 한다면 음운, 어휘, 구문 영역의 유기적인 발달을 촉진하 여 전반적인 언어 발달에 긍정적 영향을 미칠 것으로 보인다. 음운, 어휘, 구문 능력이 지연되었으나 균형적으로 발달하는 아동이라면 세 영역이 유기적으로 발달할 수 있도록 고르게 중재를 제공해야 할 것이다. 본 연구는 아동의 자발화를 토대로 음운, 어휘, 구문 능 력을 살펴보았으므로 아동이 발화를 산출할 때 특정 말소리가 포 함된 어휘나 문법형태소를 기피하였을 가능성을 배제할 수 없다. 따라서 후속연구에서는 어휘 친숙도, 어휘 길이, 문법형태소 친숙 도, 구문 길이를 조절한 구조화된 실험 조건에서도 아동의 음운, 어 휘, 구문 영역의 관계가 유기적으로 나타나는지, 불균형적으로 나 타나는지 살펴볼 필요가 있다.

\section{REFERENCES}

Bates, E., Dale, P. S., \& Thal, D. (1995). Individual differences and their implications for theories of language development. In P. Fletcher \& B. MacWhinney (Eds.), The handbook of child language (pp. 96-151). Oxford: Blackwell.

Bock, J. K. (1982). Toward a cognitive psychology of syntax: information processing contributions to sentence formulation. Psychological Review, $89,1-47$.
Chang-Song, Y. K. (2004). Early lexical development of Korean infants: 8-17 months. Korean Journal Psychology: General, 23, 77-99.

Choi, M. S., Kim, S. J., \& Kim, H. S. (2014). Lexical and phonology development in 2-year-old Korean children. Korean Journal of Early Childhood Special Education, 14, 133-152.

Donahue, M. (1986). Phonological constraints on the emergence of two-word utterances. Journal of Child Language, 13, 209-218.

Dore, J. (1979). What's so conceptual about the acquisition of linguistic structures? Journal of Child Language, 6, 129-137.

Ha, S., \& Hwang, J. (2013). Speech measures from phonological analyses of spontaneous conversations in children between 18-47 months of age. Communication Sciences \& Disorders, 18, 425-434.

Ha, S., \& Kim, M. (in press). Comparison of articulatory measures in preschool Korean children. Manuscript in preparation.

Ha, S., Seol, A., So, J., \& Pae, S. (2016). Speech and language development patterns of Korean two-year-old children from analysis of spontaneous utterances. Communication Sciences \& Disorders, 21, 47-59.

Hong, G. H., \& Sim, H. S. (2002). A longitudinal study of development of the infant's speech sounds: 18 to 24 months. Korean Journal of Communication Disorders, 7, 106-125.

Ingram, D. (2002). The measurement of whole-word productions. Journal of Child Language, 29, 713-733.

Jang, H. S., Seo, S. J., \& Ha, J. Y. (2009). Developmental assessment for the early intervention program planning. Seoul: Hakjisa.

Jung, K. H., Pae, S., \& Kim, G. (2006). The early phonological development of Korean children. Korean Journal of Communication Disorders, 11, 1-15.

Kamhi, A. G., Catts, H. W., \& Davis, M. K. (1984). Management of sentence production demands. Journal of Speech, Language, and Hearing Research, 27, 329-338.

Kim, Y. J. (1997). The acquisition of Korean. The Crosslinguistic Study of Language Acquisition, 4, 335-443.

Kim, Y. T., Kim, K. H., Yoon, H. R., \& Kim, H. S. (2003). Sequenced Language Scale for Infants (SELSI). Seoul: Special Education Publishing.

Lee, H. J., \& Kim, Y. T. (1999). Measures of utterance length of normal and language-delayed children. Korean Journal of Communication Disorders, 4 , $1-14$.

Nelson, L., \& Kamhi, A. (1984). Syntactic, semantic, and phonological tradeoffs in preschool children's utterances. Paper presented at the Annual Convention of the American Speech-Language-Hearing Association, San Francisco, CA. 
Pae, S., \& Kwak, K. C. (2011). Korean MacArthur-Bates Communicative Development Inventories (KM-B CDI). Seoul: Mindpress.

Park, H. J., Hwang, H. J., \& Park, H. (2011). A study on phonological characteristics of two-years-old children by measures of whole-word. Journal of Speech-Language \& Hearing Disorders, 20, 123-135.

Pi, M., \& Ha, S. (2017). Phonological characteristics of early vocabulary among children with cleft palate, late talking children, and typically developing children. Communication Sciences \& Disorders, 22, 328-340.

Shin, H. J., \& Lee, E. J. (2015). Phonological characteristics of late-talkers through phonological whole-word analysis. Communication Sciences \& Disorders, 20, 157-165.

Shriberg, L. D., \& Kwiatkowski, J. (1982). Phonological disorders III: a proce- dure for assessing severity of involvement. Journal of Speech and Hearing Disorders, 47, 256-270.

Storkel, H. L., \& Morrisette, M. L. (2002). The lexicon and phonology: interactions in language acquisition. Language, Speech, and Hearing Services in Schools, 33, 24-37.

Streim, N. W., \& Chapman, R. S. (1987). The effects of discourse support on the organization and production of children's utterances. Applied Psycholinguistics, 8, 55-66.

Yoon, M. S., Kim, J. M., \& Kim, S. J. (2013). Phonological whole-word measures of spontaneous speech in children two to four years of age. Journal of Speech-Language \& Hearing Disorders, 22, 69-85. 


\section{국문초록}

\section{8-30개월 아동의 자발화에 나타난 음운, 어휘, 문법 능력의 관계}

피민경 $\cdot$ 하승희 ${ }^{2}$

'한림대학교 대학원 언어병리청각학과, ${ }^{2}$ 한림대학교 언어청각학부, 한림청각언어연구센터

배경 및 목적: 본 연구의 목적은 $18-30$ 개월 한국 아동의 자발화에 나타난 음운, 어휘, 문법의 발달 현황을 살펴보고, 이 시기 아동에게 서 나타나는 음운, 어휘, 문법 능력 간의 관계를 밝히는 것이다. 방법: 생후 $18-24$ 개월 아동과 $25-30$ 개월 아동, 각 12 명씩 총 24 명에게서 수집된 자발화 중 연속 50 개 발화를 기반으로 음운 지표, 어휘 지표, 문법 지표를 분석하였다. 이를 토대로 월령 집단 간 수행력 차이와 음운 지표와 어휘 및 문법 지표 간의 상관관계를 살펴보았다. 결과: 단어단위 근접률, 단어단위 정확도, 자음정확도, 문법형태소 다양도 를 제외한 모든 음운, 어휘, 문법 측정치가 18-24개월 아동에 비해 25-30개월 아동이 유의하게 높은 결과가 나타났다. 18-24개월 아동에 게서 일부 음운과 어휘 측정치, 음운과 문법 측정치 간 정적 상관이 나타났으며, 음운과 문법 측정치에서 부적 상관도 관찰되었다. 25-30개월 아동들은 일부 음운과 어휘, 문법 측정치에서 정적 상관만 나타났다. 논의 및 결론: 본 연구 결과는 2 세 이전 아동의 자발화 에서 음운과 문법 영역 간 교환 관계가 나타나기도 하지만 2 세에 이르러서는 음운과 어휘, 음운과 문법 간 정적 상관관계를 보이며 언어 발달이 이루어진다는 점을 시사한다.

핵심어: 18-30개월, 자발화, 음운 능력, 언어 능력, 관계

\section{참고문헌}

김영태, 김경희, 윤혜련, 김화수(2003). 영유아 언어발달검사(SELSI). 서울: 도서출판 특수교육.

박희정, 황하정, 박현(2011). 단어단위 음운분석을 통한 2세 아동의 음운특성 연구. 언어치료연구, 20, 123-135.

배소영, 곽금주(2011). 한국판 맥아더-베이츠 의사소통발달평가(K M-B CDI). 서울: 마인드프레스.

신화정, 이은주(2015). 단어단위 음운분석에 의한 말 늦은 아동의 음운 특성. 언어청각장애연구, 20, 157-165.

윤미선, 김정미, 김수진(2013). 자발화 문맥에서의 단어단위 음운 평가. 언어치료연구, 22, 69-85.

이희정, 김영태(1999). 자발화 표본 분석의 정량화를 통한 언어발달지체의 판별 연구: 발화길이를 중심으로. 언어청각장애연구, 4, 1-14.

장유경(2004). 한국 영아의 초기 어휘발달: 8개월-17개월. 한국심리학회지: 일반, 23, 77-99.

장혜성, 서소정, 하지영(2008). 영아선별 교육진단검사. 서울: 학지사.

정경희, 배소영, 김기숙(2006). $12,18,24$ 개월 영유아의 음운발달 특성. 언어청각장애연구, 11, 1-15.

최민실, 김수진, 김효선(2014). 2세 전후반의 어휘능력과음운능력. 유아특수교육연구, 14, 133-152.

피민경, 하승희(2017). 구개열 아동, 말 늦은 아동, 일반 아동의 초기 어휘에 나타난음운 특성. 언어청각장애연구, 22, 328-340.

하승희, 설아영, 소정민, 배소영(2016). 자발화 분석을 통한 만 2 세 한국아동의 말-언어발달 특성. 언어청각장애연구, 21, 47-59.

하승희, 황진경(2013). 18-47개월 아동의 자발화 분석에 기초한 말소리 측정치에 관한 연구. 언어청각장애연구, 18, 425-434.

홍경훈, 심현섭(2002). 유아의 말소리 발달 특성: 18-24 개월 종단연구. 언어청각장애연구, 7, 105-124. 